\title{
Acrofacial dysostosis, Catania type
}

INSERM

\section{Source}

INSERM. (1999). Orphanet: an online rare disease and orphan drug data base. Acrofacial dysostosis, Catania type. ORPHA:1786

Acrofacialdysostosis, Catania type is a very rare type of acrofacialdysostosis (see this term) characterized by mild intrauterine growth retardation (IUGR), postnatal short stature, microcephaly, widow's peak, mandibulofacial dysostosis without cleft palate, frequent caries, mild pre- and postaxial limb hypoplasia with brachydactyly, mild interdigital webbing, simian creases, inguinal hernia and cryptorchidism and hypospadias in males. 